Pamiętnik Literacki 2012, 3, s. 225-230
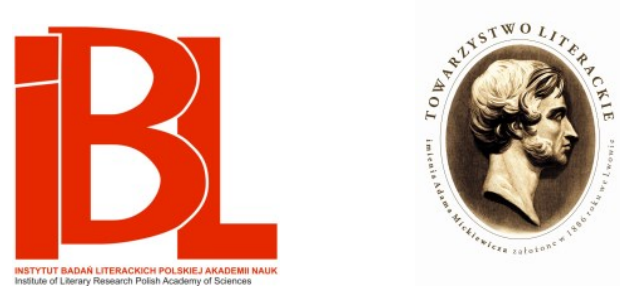

Próba rewizji. O Sienkiewiczu „pozytywnym”

Rec.: Tadeusz Bujnicki, Pozytywista

Sienkiewicz. Linie rozwojowe pisarstwa autora

„Rodziny Połanieckich”. Kraków (2007)

Tomasz Sobieraj 
TOMASZ SOBIERAJ

(Uniwersytet im. Adama Mickiewicza, Poznań)

\section{PRÓBA REWIZJI}

\section{O SIENKIEWICZU „POZYTYWNYM”}

Ta d e u s z B u j n i cki, POZYTYWISTA SIENKIEWICZ. LINIE ROZWOJOWE PISARSTWA AUTORA „RODZINY POŁANIECKICH”. (Recenzenci: Krzysztof Stępnik, Tadeusz Żabski). Kraków (2007). Collegium Columbinum, ss. 242, XL. „Biblioteka Tradycji”. Nr LXI.

Studium Tadeusza Bujnickiego o ,pozytywiście Sienkiewiczu” stanowi kolejną, szóstą już pozycję książkową w imponująco bogatym dorobku badacza na niwie sienkiewiczologii. Tym razem autorowi przyświecał zamysł rekonstrukcji głównego składnika światopoglądu i doktryny estetycznej Sienkiewicza, rekonstrukcji z pewnością nowatorskiej, bo wymierzonej polemicznie w kanon szeroko rozpowszechnionych, stereotypowych egzegez twórczości artystycznej wielkiego pisarza. Poprzednie dwie sienkiewiczologiczne książki Bujnickiego ${ }^{1}$ koncentrowały się wokół problemów powieści historycznych autora Ogniem i mieczem, jakkolwiek i tam znalazły się już studia, które niejako antycypowały rozwinięty teraz przez badacza interpretacyjny projekt swoistej „repozytywizacji” Sienkiewicza. Mam tu głównie na myśli syntetyczne szkice: Sienkiewiczowska koncepcja powieści historycznej oraz ,, Trylogia” w kontekście dziewiętnastowiecznej powieści historycznej, ukazujące ścisły związek modelu powieści historycznej Sienkiewicza z poetyką powieści realistycznej, skodyfikowaną i lansowaną przez pozytywistyczną krytykę literacką.

Powiedzieć trzeba, że najnowsza książka Bujnickiego potwierdza wszystkie doskonale znane - prawdziwie pozytywistyczne, by tak rzec - zalety warsztatu badawczego autora, przede wszystkim nadzwyczajny wprost respekt dla historycznoliterackiego faktu, obiektywizm dyskursu (m.in. objawiający się w wielostronnym ujmowaniu przedmiotu i rzeczowym toku narracji) oraz umiejętność budowania uogólnień, które nie są żadnymi apriorycznymi spekulacjami, lecz, wprost przeciwnie, mocno się ugruntowują na materiale empirycznym. Tezą przewodnią książki - niewątpliwie odkrywczą i przekonująco udowodnioną poprzez szczegółowe analizy i interpretacje - jest stwierdzenie o istnieniu pozytywistycznego fundamentu w światopoglądzie ideowym oraz estetyce Henryka Sienkiewicza.

Pozytywista Sienkiewicz... Ta fraza wydaje się na pozór kontrowersyjna, szczególnie obecnie, kiedy to w badaniach nad literaturą polskiego pozytywizmu zdecydowanie dominuje taki rodzaj egzegez, które przede wszystkim akcentują najrozmaitsze sposoby artystycznych i światopoglądowych rewizji pozytywistycznego paradygmatu, ukazując jego „pęknięcia”, niekonsekwencje i ukryty potencjał „metafizyczny” (w rezultacie to, co uchodzi za konsekwentnie pozytywistyczne, w sensie zarówno światopoglądowo-filozoficznym, jak estetycznym, zepchnięto na dalszy plan...). Poza tym na niwie polskiej sienkiewiczologii trudno byłoby odnaleźć prace wolne od różnych ideowo-światopoglądowych presupozycji, aktualizowanych potem - mniej lub bardziej jawnie - w praktyce badawczej ${ }^{2}$.

1 T. B u j n i c k i: Sienkiewicza „Powieści z lat dawnych”. Studia. Kraków 1996; Światopoglad i poetyka. Szkice o powieściach historycznych Henryka Sienkiewicza. Rzeszów 1999.

2 Wyjątkiem wydaje się książka J. S z ta c h els k i e j Czar i zaklęcie Sienkiewicza. Studia $i$ szkice (Białystok 2003). Autorka unika wprawdzie apriorycznych formuł ideowych, w które zwykło się ujmować dzieło Sienkiewicza, wszakże tezą scalającą przedstawioną przez nią interpretację dorobku pisarza jest stwierdzenie o jego ,polimorficznym” charakterze, wymykającym się jednoznacznym klasyfikacjom, interferującym z różnymi kontekstami literackimi, filozoficznymi i antropologiczno-kulturowymi. 
Tak np. często uprzywilejowuje się narodowo-katolicki wymiar pisarstwa Sienkiewicza, czyniąc zeń - w tonacji wyraźnie apologetycznej - autorytatywnego twórcę polskiej świadomości kulturalnej w wariancie tradycjonalistycznym ${ }^{3}$.

Na tym tle książka Bujnickiego wyróżnia się jak najkorzystniej. We wstępie odnajdujemy autorską deklarację badawczą, w pełni świadomie uwydatniającą rewizjonistyczny (w stosunku do dominujących nurtów sienkiewiczologii) charakter całości: „W zaprezentowanych w tomie pracach kierunek interpretacji jest inny. Mniej jednoznaczny, natomiast bardziej synkretyczny, godzący ze sobą sprzeczności obecne w twórczości Sienkiewicza. Zarazem akcentujący szczególne znaczenie pozytywistycznej »inicjacji«. Kluczowymi pojęciami tej interpretacji są przede wszystkim kategorie: pozytywizmu (rozumianego zarówno jako program społeczny, jak i - scientyczny [!] światopogląd), realizmu (pojmowanego jako specyficzny typ Sienkiewiczowskiego mimetyzmu, niezwykle sensualistycznego [...]), wreszcie »klasycyzmu« - jako akceptowanej przez pisarza doktryny estetycznej" (s. 8-9). Rzecz jasna, owa analiza i interpretacja pozytywistycznych składników światopoglądu i estetyki Sienkiewicza sumiennie odnotowuje istnienie elementów innorodnych, ważnych przecież dla uformowania osobowości twórczej pisarza. Bujnicki bowiem, jak wspomniałem, nie narzuca apriorycznej tezy historycznoliterackim faktom, on je starannie ujmuje w nową konstrukcję interpretacyjną, przy czym - z podziwu godnym obiektywizmem - przytacza też opinie odmienne, sprzeczne z jego wizją Sienkiewicza pozytywisty...

Książka została skomponowana w taki sposób, iż w jej części pierwszej (zatytułowanej właśnie Pozytywista Sienkiewicz) mieszczą się m.in. dwa studia o charakterze syntetycznym, w drugiej zaś i trzeciej - artykuły rozpatrujące dany aspekt twórczości pisarza w powiązaniu z tezą przewodnią całości. Studium o ,plemiennej sile” Sienkiewicza rekonstruuje główne składniki krytyczno- i historycznoliterackiej recepcji twórczości autora Quo vadis, skupionej na odkrywaniu, by tak rzec, jej faculté maîtresse. Znalazły się tutaj - rzeczowo, acz (niekiedy) krytycznie omówione - sądy Elizy Orzeszkowej, Stanisława Witkiewicza, Stanisława Brzozowskiego, Stefana Żeromskiego, Władysława Reymonta, Juliusza Kleinera, Witolda Gombrowicza, Teodora Parnickiego, Kazimierza Wyki, Ewy Kosowskiej, Jolanty Sztachelskiej... Bujnicki skonfrontował je z wypowiedziami samego Sienkiewicza, które zresztą stanowią w książce stały punkt odniesienia dla historycznoliterackich uogólnień i hipotez. Autor Trylogii urasta tutaj do rangi wybitnego wyraziciela i zarazem twórcy polskiej świadomości narodowej i patriotycznej, gdyż z jego powieści, jak przenikliwie to zauważył Witkiewicz, „,buchnęła [...] elementarna siła narodowego życia z taką mocą sugestyjną, że ludzie wątpiący ocknęli się i kajali się za swoją niewiarę, za poniżenie dusz własnych, które było poniżeniem wielkiej przeszłości i tej przyszłości, w którą nikt żywy nie wątpi”. Idea powieści Sienkiewiczowskich - przekonywał krytyk - zawiera się w przesłaniu, że ,naród stanowi tylko ta elementarna siła jego osobowości, ta niepokonana żywotność jego treści plemiennej, która ogarnia całość życia i nadaje wszelkim jego przejawom swoją szczególną cechę. Tę treść plemienną, ten absolutny pierwiastek narodowości wskrzesiła poezja Sienkiewicza i w tym tkwi ogrom jej znaczenia i przyczyna tej czci, którą naród go otoczył" ". I jakkolwiek inaczej na twórczość pisarza zapatrywali się jego ideowi oponenci, przede wszystkim Stanisław Brzozowski, Wacław Nałkowski, ale i Bolesław Prus, surowo krytykujący uprawianą przezeń mitologię narodową, to jednak faktem jest, że Sienkiewicz odegrał kluczową rolę w wytworzeniu i utrwalaniu wielu stereotypów patriotycznych o nadzwyczaj długiej żywotności. Siła ich oddziaływania tkwiła też, rzecz jasna, w formie artystycznej, w jaką przyoblekł je autor Trylogii...

3 Silny nurt w praktykach egzegetycznych twórczości Sienkiewicza stanowią badania jej horyzontu religijnego, których animatorem jest zwłaszcza L. L u d o r o w s k i - zob. np. opracowaną przezeń, silnie konfesyjną książkę Motywy religijne twórczości Henryka Sienkiewicza (Kielce 1998).

4 S. W it k i e w i c z, Juliusz Kossak. W: Pisma zebrane. Red. J. Z. Jakubowski, M. Olszaniecka. T. 2, cz. 1. Rozprawa wstępna i komentarz M.: O 1 s za n i e c k a. Kraków 1974, s. 9. 
Nie ulega wszak wątpliwości, że najważniejszym ogniwem książki Tadeusza Bujnickiego jest studium Pozytywista - neokonserwatysta ${ }^{5}$. To - nie waham się użyć takiego określenia - bodaj najwybitniejsza, najbardziej odkrywcza i inspirująca praca sienkiewiczologiczna początku XXI stulecia. W literaturze przedmiotu problem pozytywistycznych właściwości światopoglądu Sienkiewicza ujmowano dotąd raczej pobieżnie; często bezkrytycznie przytaczano opinię samego pisarza, iż w ,pozytywistycznym słoneczniku” kręcił się, za młodu, dość przypadkowo, przelotnie i bez wewnętrznego przekonania. Koronnym dowodem tej tezy jest właśnie słynny, wielokrotnie przywoływany i komentowany list Sienkiewicza do Konstantego M. Górskiego z 1895 roku, napisany, co godzi się podkreślić, w atmosferze głębokiego kryzysu pozytywizmu, w czasie idealistycznej „reakcji”, którą on sam deklaratywnie wspierał ${ }^{6}$. Oczywiście, nie sposób lekceważyć tych przejawów autorskiej, „antypozytywistycznej” świadomości Sienkiewicza, jednakże błędem byłby brak ich weryfikacji w zestawieniu z wypowiedziami innymi, nierzadko przeciwstawnymi, oraz z ideologią immanentną dzieł literackich pisarza czy też z jego ogólnym nastawieniem epistemicznym i metodologicznym, dość silnie, jak się wydaje, przenikniętym właśnie cechami pozytywnymi, które znacząco determinowały jego myślenie o świecie i literaturze.

Do historycznoliterackich truizmów zalicza się dziś twierdzenie o ewidentnie tendencyjnym i pozytywistycznym charakterze wczesnej prozy Sienkiewicza (opowiadań z cyklu Humoreski z teki Worszytly, opublikowanego w 1872 roku). Bujnicki zwraca nadto skrupulatną uwagę na bardzo silne akcenty radykalizmu ideowo-światopoglądowego, objawione w tekstach pisarza pochodzących z lat siedemdziesiątych XIX wieku. Z pewnością można je potraktować jako przekonujący dowód związków świadomości Sienkiewicza $\mathrm{z}$ atmosferą intelektualną tamtej doby, kształtowaną przez hasła pozytywistyczne. Badacz uwydatnia znaczenie Listów z podróży do Ameryki oraz Listów z Paryża jako niekwestionowanych świadectw światopoglądowego aliansu pisarza z pozytywizmem i ideowym radykalizmem. Bujnicki zauważa, że np. w tych drugich Sienkiewicz ,wyraźnie się [...] deklaruje jako zwolennik ówczesnej francuskiej Rzeczypospolitej. Ironicznie pisze o francuskich zwolennikach Ancien Régime'u, a z uznaniem o przygotowaniach do rocznicy Wolterowskiej. Wreszcie przedstawia się jako zwolennik radykalnego postępu, w którym istotną rolę odegrają warstwy »niższe«" (s. 33).

I choć na początku lat osiemdziesiątych nastąpił słynny zwrot Sienkiewicza w kierunku konserwatywnym (udokumentowany instytucjonalnie objęciem stanowiska redaktora „Słowa”), to przecież refleksy młodzieńczej edukacji pozytywistycznej przejawiały się potem - choć nieco stłumione - w różnych konfiguracjach zarówno w jego programie estetycznym, jak i w poglądach społecznych. Bujnicki podkreśla: „Sienkiewicz, skłaniając się nawet ku konserwatyzmowi, w swojej publicystyce zachowuje wyraźne miejsce dla interpretacji według kryteriów, które wyniósł z »terminowania« u pozytywistów. W ocenach rzeczywistości społecznej nadal są ważne teorie cywilizacyjnego postępu, »pracy organicznej« i »pracy u podstaw«. Na gruncie estetycznym jest to mocne wsparcie wizji artystycznej o wyznaczniki »metody realnej«, racjonalizowanie obrazu świata nawet tam, gdzie

5 Wcześniej zostało ono opublikowane pt. Sienkiewiczowski pozytywizm. Presja idei i artystyczny obraz świata w zbiorze Henryk Sienkiewicz. W stulecie Nagrody Nobla (Red. T. Lewandowski, W. Maciejewski. Poznań 2006).

6 H. S i enki ewi c z (Listy. T. 1, cz. 2: Mścisław Godlewski - Władysław Jabłonowski. Wstęp, biogramy adresatów J. K r z y ż a n o w s k i. Oprac. M. B o k s z c z a n i n. Warszawa 1977, s. 293) pisał w tym liście $z$ odczuciem dużego dystansu do atmosfery ideowej wczesnego pozytywizmu: „Pan należąc do młodszego pokolenia może nie zdaje sobie sprawy, co się działo w Warszawie za dobrych pozytywnych czasów, gdy Boga pisało się przez małe b, gdy racjonalizm był synonimem rozumu i gdy nawet ludzie religijni, mniej śmiałej natury, trzymali się ideału i religii jakoś wstydliwie... Ja z tym nastrojem nie polemizowałem wprost - kręciłem się nawet w tym pozytywistycznym słoneczniku sam, ale był mi on sans le savoir wstrętny, zwłaszcza zaś przeciwny moim artystycznym poczuciom". 
pisarz podejmował wątki religijne i przedstawiał zjawiska nadprzyrodzone i niewytłumaczalne" (s. 33).

Za szczególnie istotne - acz z pozoru nieefektowne i lapidarne - uważam parokrotnie pojawiające się na kartach książki twierdzenie o (zasadniczo) realistycznym charakterze twórczości artystycznej Sienkiewicza ( $n b$. Bujnicki sumiennie odnotowuje wylansowanie tej tezy interpretacyjnej przez Ignacego Matuszewskiego ${ }^{7}$ ). Wnikliwie analizy tak metody twórczej, jak i poetyki immanentnej dzieł pisarza w pełni ten sąd potwierdzają ${ }^{8}$. Zresztą akurat związki poglądów estetycznych pisarza $\mathrm{z}$ dominującym $\mathrm{w}$ czasach pozytywizmu modelem literatury mimetycznej dostrzegano i całkiem wyczerpująco omawiano ${ }^{9}$. Zwróciłbym tylko uwagę na fakt, że do metodologii (i epistemologii) pozytywizmu Sienkiewicz niejednokrotnie też się odwoływał w swojej praktyce krytycznoliterackiej, która odznaczała się właściwościami typowymi dla pozytywistycznego dyskursu krytycznoliterackiego. Dodatnio więc waloryzował kategorię ,realizmu” (w latach osiemdziesiątych przeciwstawiał go ,jednostronnemu" naturalizmowi), domagając się od wartościowego utworu literackiego „,prawdy życiowej”, która - jak czytamy w jego młodzieńczej recenzji z 1873 roku - „oparta [jest] na spostrzeżeniach branych z rzeczywistości" ${ }^{10}$. Sienkiewicz, dodajmy, stale wymagał od pisarzy, by, pilnie bacząc na kształt życia empirycznego, potrafili jednak - wzorem dyrektyw metodologicznych Hippolyte'a Taine'a - nadać światu przedstawionemu dzieła cech spójnej całości i zorganizowali je w zwarty porządek, ukazujący np. jakąś prawidłowość natury ${ }^{11}$. Podkreślając rangę czynnika racjonalnego w procesie twórczym (podnoszone właśnie przez Taine’a), Sienkiewicz z wielkim uznaniem odnosił się też do empirycznej, wręcz sensualistycznej epistemologii, znakomicie odwzorowanej w dziełach skądinąd krytykowanego przezeń Émile’a Zoli, któremu przyznawał miano „realisty w całym znaczeniu tego wyrazu" (s. 98). Pomimo zbędnego natłoku szczegółów zaobserwowanych - powieści Zoli mają niewątpliwie tę zaletę, iż, jak zanotował Sienkiewicz, „wszystko, co nam [on] opisze, mamy, widzimy, pamiętamy” ${ }^{12}$. Tadeusz Bujnicki, prze-

${ }^{7}$ I. Matuszewski (Swoi i obcy. W: O twórczości i twórcach. Studia i szkice literackie. Wybór, oprac. S. S a ndle r. Warszawa 1965, s. 118), recenzując Rodzinę Połanieckich, orzekł o Sienkiewiczu: „Jest to realista najczystszej wody, i to w najszlachetniejszym stylu. [...] każda [bowiem], choćby nawet najbanalniejsza, postać wychodzi spod pióra autora Potopu jako istota z krwi i ciała, pełna, żywa, realna, podobna do nas i naszych znajomych. Ludzie ci, zbudowani w sposób mistrzowski z pierwiastków znanych nam doskonale, są niejako uosobieniem prawdy i życia [...]”.

${ }^{8}$ Nawiasem mówiąc, już w jednym ze swoich wcześniejszych studiów, ,,Trylogia” w kontekście dziewiętnastowiecznej powieści historycznej (włączonym do książki Sienkiewicza „Powieści z lat dawnych”, T. B u j n i c ki dowiódł, iż Sienkiewicz stworzył w Trylogii model ,pozytywistycznej powieści historycznej”, wykorzystując kategorie poetologiczne i metodę pisarską, charakterystyczne dla poetyki dojrzałego realizmu.

${ }_{9}$ Uczynił to T. Ż a b sk i w książce Poglady estetyczno-literackie Henryka Sienkiewicza (Wrocław 1979).

${ }^{10}$ H. S i e n k i e w i c z, Przeglad literacki. „Czarna nić”. Powieść Felicjana Gryfa - ,Sabina” Michała Bałuckiego. W: Dzieła. Red. J. Krzyżanowski. T. 45. Warszawa 1951, s. 223.

${ }^{11}$ Sądzę, że „matrycę” Taine'owskiej metodologii twórczości wykorzystał H. S i e n k i e w i c z (Szkice literackie. II. Pisma Bolesława Prusa: „, Przygoda Stasia”. „,Powracajaca fala”., ,Michałko”. „Sieroca dola”. W: jw., s. 296) w swojej recenzji dzieł Prusa, gdy stwierdzał: ,[Prus] nie baczy na to, że powieściopisarz powinien właśnie takie wybierać fakta, tak je grupować i ustawiać, by tworzyły całość - i że takie org a n i zow a n i e jest poniekąd zadaniem powieści. Życie dla autora powieściowego jest tym, czym glina dla rzeźbiarza, która dostarcza mu realnego materiału, ale sama przez się jest bezkształtną. Dopiero pod ręką artysty, zapatrującego się na kształty życiowe, nabiera ona form plastycznych. Ale czerpiąc ogólne wzory w naturze, artysta winien umieć zrobić wybór, winien tchnąć w nią własnego ducha, zaprowadzić ład artystyczny i wyrazić przez nią swój ideał. Jest to twórczość wyższa nad naśladowanie natury, w której z konieczności mieści się już pojęcie organicznego planu".

${ }^{12}$ H. S i e n k i e w i c z, O naturalizmie pwpowieśsi. LI. Wf jw., s. 98-99. 
chodząc na poziom poetyki immanentnej Sienkiewicza, wielokrotnie podkreśla iluzję realności, uzyskiwaną dzięki „,czynnikom wyobrażeniowym” i obrazowo-plastycznym, trwale istniejącym w strukturze dzieł pisarza, wywołującym u czytelnika właśnie „odbiór wyraziście sensualistyczny" (s. 29).

Szkice interpretacyjne poświęcone poszczególnym powieściom, a więc Bez dogmatu, Rodzinie Połanieckich, Quo vadis i Wirom, nie stanowią wyłącznie tekstów autonomicznych, niezależnych od siebie, przeciwnie - nicią łączącą je jest poszukiwanie mniej lub bardziej ukrytych śladów pozytywistycznych. O związkach powieści Bez dogmatu z filozofią pozytywną oraz z naturalistyczną koncepcją literatury jako „dokumentu ludzkiego” pisano już wielokrotnie. Bujnicki problematykę tę, oczywiście, omówił, koncentrując się wszakże raczej na analizie i interpretacji „konwencji gatunkowych” utworu, wśród których pierwszoplanowe miejsce przypadło dziennikowi-pamiętnikowi i listom (strukturę i funkcję powieściową tych ostatnich autor ukazał wielopłaszczyznowo i nowatorsko). Ale swoją uwagę skupił też na horyzontach poznawczych Bez dogmatu; tutaj uwzględnił kwestię dekadentyzmu Sienkiewicza (rozpatrywanego zresztą kompleksowo, tzn. na przykładzie także innych powieści oraz inklinacji światopoglądowych samego pisarza), temat „newrozy pieniężnej”, jak i intertekstualny dialog z różnymi sztukami, ,zakodowany” w strukturze Bez dogmatu, istniejący również w Quo vadis. Za najważniejszą postać tej drugiej powieści uznał badacz Petroniusza, przeciwstawiając się uproszczonym egzegezom odnajdującym w niej jednoznaczną apologię rodzącego się chrześcijaństwa (oczywiście, Bujnicki tezy takiej całkowicie nie zarzuca). Tymczasem sens globalny Quo vadis nie wydaje się wcale tak przejrzysty, są w nim pewne rysy i antynomie, objawione przede wszystkim w wyjątkowej pozycji Petroniusza, bohatera (jak ongiś przypuszczał już Kleiner ${ }^{13}$ ) najbliższego światopoglądowo Sienkiewiczowi, reprezentującego takie stanowisko filozoficzne i estetyczne, ku któremu on sam niekiedy się skłaniał. Artystyczny obraz świata w Quo vadis może nawet częściowo się rozmijać z apologetycznymi intencjami pisarza. Jak bowiem zauważa Bujnicki: „,kreacja Petroniusza ma sens zasadniczy dla rozstrzygania o charakterze utworu. [...] Niezależnie od założeń autora, modyfikuje ona przesłanie powieści i zaciera jego jednoznaczność. Nie daje zatem oczywistego rozstrzygnięcia w konflikcie dwóch światów. Klęska Nerona nie oznacza [...] klęski reprezentowanych przez Petroniusza wartości estetycznych i filozoficznych. Przeciwnie, nadaje im sens »długiego trwania«" (s. 216).

Interpretacje powieści współczesnych Sienkiewicza, Rodziny Połanieckich i Wirów, przeprowadził Bujnicki na szerokim tle zarówno przemian światopoglądowych i ideowych autora, jak i kontekstu ,zewnętrznego” epoki. Badacz zaakcentował występowanie pierwiastków pozytywistycznych w Rodzinie Połanieckich, przytłumionych wszakże konserwatywną tendencją ideową. Studium o tej powieści zamyka interesująca teza o swoiście arealistycznym charakterze stereotypu idealnej rodziny (Połanieckich), który załamuje się w zderzeniu z prawdą rzeczywistości. Z pewnością trafna wydaje się supozycja o biedermeierowskich cechach utworu. Jej - jak sądzę - pozytywną weryfikację zapewniłaby bardziej szczegółowa i pogłębiona analiza oraz interpretacja struktury semantycznej całości.

Rzeczowo i przekonująco wypadła w książce próba odczytania Wirów, powieści ostatnio niekiedy przecenianej. Bujnicki, podobnie jak czynił to wcześniej w stosunku do Rodziny Połanieckich (a nawet do Quo vadis! ${ }^{14}$ ), nie waha się otwarcie wskazać mielizn arty-

13 Zob. J. K 1 e i n e r, Artyzm Sienkiewicza. W: Trylogia Henryka Sienkiewicza. Studia, szkice, polemiki. Wybór, oprac. T. J o d ełk a. Warszawa 1962, s. 357. Jednakże Kleiner podkreślił klasycystyczny rys światopoglądu pisarza, uobecniony właśnie w postaci Petroniusza.

${ }^{14}$ Syntetyczna ocena Quo vadis, wystawiona przez Bujnickiego, brzmi w kontekście egzegez apologetycznych szczególnie „ożywczo”: „Mimo długotrwałego i olbrzymiego powodzenia trudno uznać powieść Sienkiewicza za dzieło wybitne. Także wśród utworów pisarza nie uchodzi ono za dzieło najważniejsze. Poziomem artystycznym nie dorasta Trylogii, koncepcją i głębokością spoitto.ticll.org. ol 
stycznych utworu; odnajduje je przede wszystkim w jego ,silnej konwencjonalizacji” na płaszczyźnie fabularnej, w wielu uproszczeniach natury publicystycznej i w ,tendencyjnym banale" (s. 146). Zarazem jednak dostrzega podjętą przez Sienkiewicza próbę (w miarę obiektywnego) odwzorowania różnych postaw ideowych polskiej inteligencji w burzliwym czasie rewolucji 1905 roku. Koryfeuszem ideologicznym powieści jest pozytywista (!) doktor Szremski, ,wykreowany na obraz i podobieństwo stereotypowych postaci pozytywistów wczesnej prozy tendencyjnej”" (s. 141). Postulaty reformistyczno-organicznikowskie łączy Szremski z koniecznością obrony polskiej tkanki narodowej przed napływem „,wirów” ze Wschodu. Ów interesujący alians pozytywizmu z ideą narodową (,aryjskim duchem" Polski, gloryfikowanym już wcześniej przez profesora Waskowskiego w Rodzinie Połanieckich) to rdzeń poglądów ,późnego” Sienkiewicza na sprawy polskie. W okresie rewolucji 1905 roku wcale nieodległe stanowisko ideowo-polityczne prezentował też Bolesław Prus...

Książkę zamyka znakomite studium Sienkiewicz oglądany - Sienkiewicz czytany, w którym autor znowuż zaprezentował, pozytywistyczne z ducha, przeniknięte krytycyzmem i nastawione na rewizję wielu stereotypów odczytanie ,stylów odbioru” Sienkiewicza, w tym dominującej ostatnio recepcji obrazowej (filmowej), nakierowanej na odnajdywanie w dziele pisarza funkcji ludycznej. Bujnicki zauważa, iż niejaką „odpowiedzialność” za ten rodzaj recepcji ponoszą sam artysta i jego dzieło, nacechowane (także) właściwościami typowymi dla literatury (kultury) popularnej, a więc choćby wartką i dynamiczną, pełną nagłych zwrotów akcją, wieloma elementami przygodowymi, rozbudowanymi wątkami erotycznymi oraz - co szczególnie istotne dla wpływu Sienkiewicza na polską świadomość zbiorową - funkcją kompensacyjną, ugruntowującą pewne narodowe i patriotyczne stereotypy. Szczególnie przy tym znamienne, że krakowski uczony wielokrotnie - i bynajmniej nie w duchu polemicznym! - przywołuje słynną opinię Witolda Gombrowicza, który w Sienkiewiczu widział zarówno twórcę łatwych „efektów zewnętrznych”, jak kodyfikatora (i poniekąd demaskatora) narodowej mitologii i polskich kompleksów.

Sienkiewicz oglądany, wytwór współczesnej kultury masowej, to artysta uproszczony, sprymitywizowany, podatny na liczne manipulacje natury ideowo-światopoglądowej, słowem - jednowymiarowy. Bujnicki, jak najsłuszniej, dopomina się o reaktywację Sienkiewicza czytanego, tyle że czytanego odmiennie, niż to zwykło się praktykować w niektórych nurtach polskiej sienkiewiczologii. Konkluduje: „Pod powierzchnią lektury naskórkowej, może nawet wbrew niej, kryją się w utworach pisarza elementy nieoczekiwane i niestereotypowe. Pod wieloma względami możliwe do przewartościowania i reinterpretacji" (s. 240). Próbę takiej odnowionej lektury dzieła Sienkiewicza podjął w swojej książce Tadeusz Bujnicki. Doniosłość wielu postawionych w niej hipotez powinna by ożywić współczesną sienkiewiczologię.

\section{Abstract}

TOMASZ SOBIERAJ

(Adam Mickiewicz University, Poznań)

\section{AN ATTEMPT AT REVISION. ON "POSITIVE” SIENKIEWICZ}

The review discusses Tadeusz Bujnicki's book Sienkiewicz the Positivist. Lines of development of the author of "Polaniecki Family [Rodzina Połanieckich]" on the analysis and interpretation of Henryk Sienkiewicz's worldview and his main aesthetic assumptions. In the innovative characteristics of Sienkiewicz's positivism Bujnicki allows for Sienkiewicz's poetics and features of his writing technique as well as reconstructs the meanders of the writer's ideological attitude.

strzeżeń - Bez dogmatu. Powieść »z czasów Nerona« nie zawsze mogła udźwignąć ciężar przedstawianego konfliktu, a ramy konwencjonalnego romansu niewątpliwie trywializowały jego charakter. Komponując wielkie efektowne sceny-»obrazy«, Sienkiewicz nierzadko popadał w przesadny patos lub sentymentalizm oraz stosunkowo łatwo poddawał się stereotypom" (s. 184-185). 